FOCUS: Journal of International Business Volume 4, Issue 1, January-June 2017, pp. 63-82 doi: 10.17492/focus.v4i01.9541

\title{
Economic Development and Climate Change: An Empirical Study for Developing Nations
}

\author{
Megha Jain*
}

\section{ABSTRACT}

Climate change does not yet feature conspicuously within the environmental or economic policy agenda of developing countries. Yet evidence shows that some of the most unfavourable effects of climate change will be in developing countries, where populations are most susceptible and least likely to easily adapt to climate change. The Environmental Kuznets Curve (EKC) hypothesis postulates the existence of an "inverted-U" shape relationship between per capita GDP and measures of environmental degradation. Various studies have addressed the direct relationship between environmental degradation and expanding economic activity so far. However, there is a need to establish the sustainable growth pairing with climate impact. This study examines the impact of economic development factors (Output, Energy usage, Direct Foreign Investment) on carbon emissions across BRIC economies and other developing nations, graphically using EKC hypotheses and empirically using GMM. Panel data over period 1991 to 2011 is used. The results validate that economic growth factors are elements of environmental quality in BRIC and developing economies. The paper indicates the relevance of making climate change policies a mainstream goal for global governance through increased carbon spacing.

Keywords: Carbon emissions; Climate; Economic growth; EKC; Environment degradation.

\subsection{Introduction}

The increasing threat of global warming and climate change has been a major, worldwide, on-going concern during the last two decades. Since the completion of 1st Assessment Report (AR) by Intergovernmental Panel on Climate Change (IPCC) in 1990 under the framework of United Nations Framework Convention on Climate Change (UNFCCC), climate has been the extensive public controversial issue.

*Research scholar, Faculty of Management Studies, University of Delhi, Delhi, India. (Email id: megha.j_phd15@fms.edu; mmeghajain@gmail.com) 
The 1997 Kyoto protocol had the objective of reducing greenhouse gases (GHG) that cause climate change. It demanded the reductions of Greenhouse Gases (GHG) emissions to 5.2\% lower than the 1990 level during the period 2008-2012 and came into force in 2005. Amongst several environmental pollutants causing climate change, carbon dioxide $\left(\mathrm{CO}_{2}\right)$ was held responsible for $58.8 \%$ of the GHG (The World Bank, 2011). Though BRIC countries (Brazil, Russian Federation, India, and China) signed the Kyoto protocol to curb emission levels, there are still environmental concerns given the region's recent economic growth (Pao and Tsai, 2010).

The recent Paris Climatic Undertaking (2015) by developed and developing nations in an integrated apportionment of carbon spacing further supports the force of BRIC nations in the world economy than G6 coalition (Goldman Sachs, 2003). In 1990, BRIC countries emissions were as follows: Brazil's 0.94\%, the Russian Federation's $3.80 \%$, India's $3.00 \%$ and China's $11.00 \%$ of the world emissions. By 2011, BRIC countries emissions increased for their economies, Brazil at 2\%, Russia 5\%, India $6 \%$ and China $29 \%$ of the world emissions (The World Bank, 2011). Vulnerability to climate change will mainly depend on economic position and infrastructure energy consumption potential of a nation. Climate change effects will impose significant additional stress on ecological and socioeconomic systems. These systems are currently burdened by pollution, natural resource scarcities and other unsustainable practices.

India has emerged as the world's fastest-growing major polluter and is the single most critical player when it comes to global climate change. Bucking a worldwide trend of slowing carbon emissions, India's emissions grew quicker in 2014 than they had ever done before. This holds serious implications for climate change. In a developing country, climate change is an additional burden because these systems are already facing pressures from rapid population, industrialization and economic development. India's climate could become warmer under conditions of increased atmospheric $\mathrm{CO}_{2}$ (Longerman, 1998). Projections by several international agencies including the World Bank show that the Indian economy is expected to grow faster than any other major economy, including China. This may unveil future deleterious environmental effects. The average temperature change is predicted to be in the range of $2.33^{\circ} \mathrm{c}$ to $4.78^{\circ} \mathrm{c}$ for India, with the doubling in $\mathrm{CO}_{2}$ concentrations (as per IPCC $2^{\text {nd }}$ Assessment Report). Plans to set up new factories (under the campaign) promise to magnify the quantum of harmful gases intensity in time ahead. With upcoming power projects, new investment plans of roads and highways construction and recent placement of investor-friendly policy; makes it essential to think on the transition to a low carbon economy.

Figure 1 presents the carbon emissions per capita for BRIC nations from 1991 to 2011. The increasing height of the bars verifies the escalating trend of carbon adverse 
impact for this group of nations in years to come. The potential is matchless for China and Russia followed by India and Brazil. . It is often argued that BRIC economies could become a much larger force in the world economy than G6 in less than 40 years. By 2025, they could account for over half the size of the G6. $\mathrm{CO}_{2}$ emissions, once thought to be a harmless by-product of combustion, are now believed to be the primary greenhouse gas responsible for the problem of global warming (IPCC, 2007).

Figure 1: Carbon emissions (metric tons per capita) for BRIC nations: 1991-2011

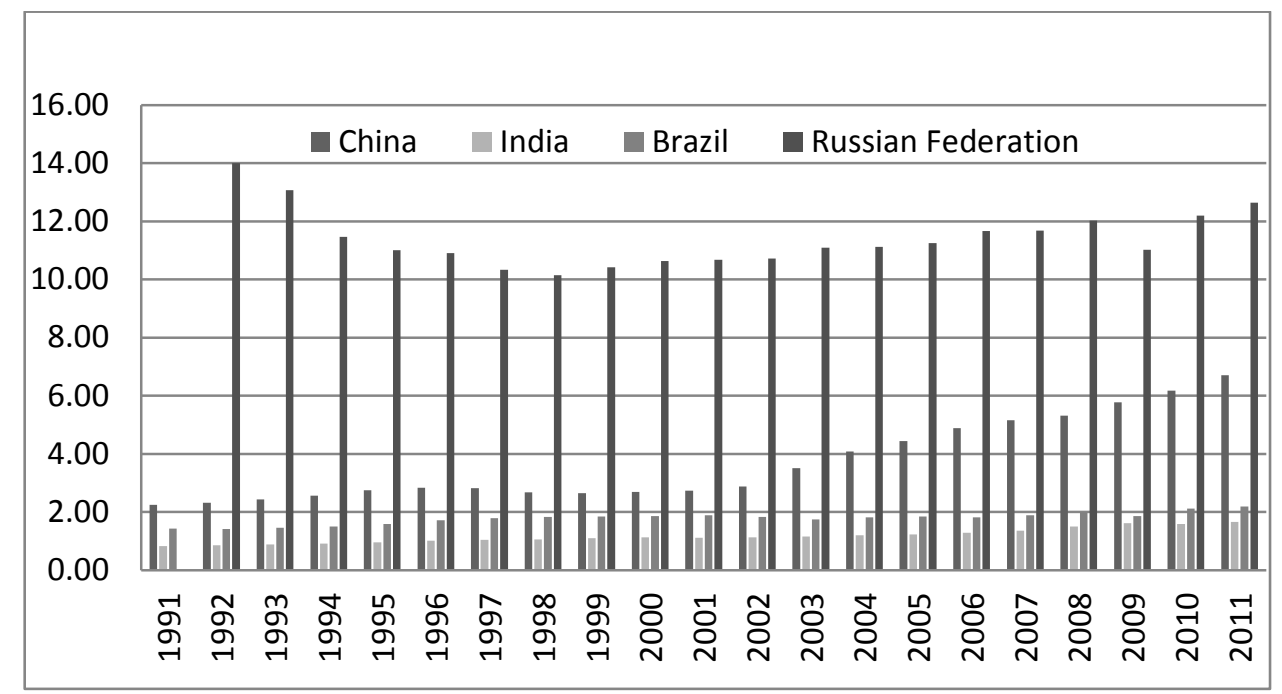

Source: World Development Indicators

Economic growth, increasing prosperity, growing rate of urbanisation and rising per capita energy consumption has widened access to energy in the developing countries (IPCC, 2014). The effects are amplified with emission of gases from various anthropogenic activities consequent to industrialisation and urbanisation. In the current energy driven developing countries, end-use 'energy services' are mainly energised directly or indirectly by, oil, natural gas, and coal. Till date, despite of unlimited growth potential for the solar photovoltaic industry, approx. $85 \%$ of the energy requirements are met by fossil fuel (non-renewable energy sources) in India. India's reliance on fossil-fuel based electricity generation has aggravated the problem of high carbon dioxide $\left(\mathrm{CO}_{2}\right)$ emissions from combustion of fossil fuels, primarily coal, in the country's energy sector. If energy consumption grows in line with forecasts by the International Energy Agency (IEA) and many others, the world will consume about $40 \%$ more energy than it uses 
66 | FOCUS: Journal of International Business, Volume 4, Issue 1, January-June 2017

today, with little change to the mix of energy sources and both biofuels use and energy efficiency investments continuing at their current pace. By just about any measure - oil supplies, energy security, $\mathrm{CO}_{2}$ or other emissions - such growth in energy demand threatens the sustainability of the green growth resulting in 'Climatic Mortification'. Figure 2 ( $\mathrm{i}$ and ii) lays down 'energy use ( $\mathrm{kg}$ of oil equivalent per capita) from 1991 to 2012 and 'fossil fuel energy consumption (\% of total) in 2012 for BRIC economies.

Figure 2(i): Energy Use (kg of oil equivalent per capita) of BRIC Economies: 1991 to 2012

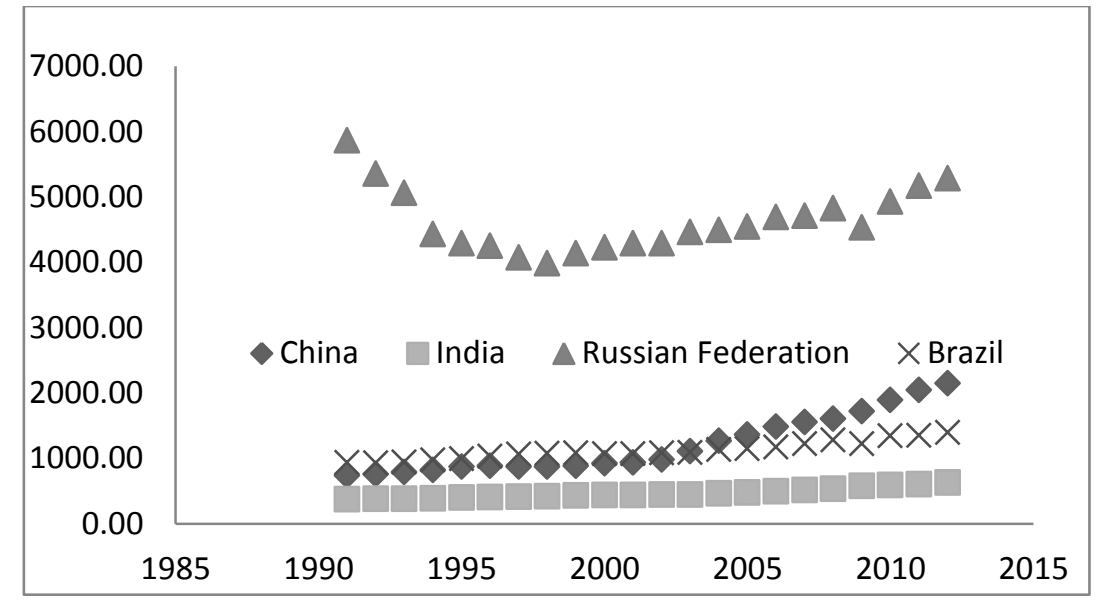

Source: Author's adaptation from WDI databank

Figure 2(ii): Fossil Fuel Energy Consumption (\% of total) of BRIC Economies: 1991-2012

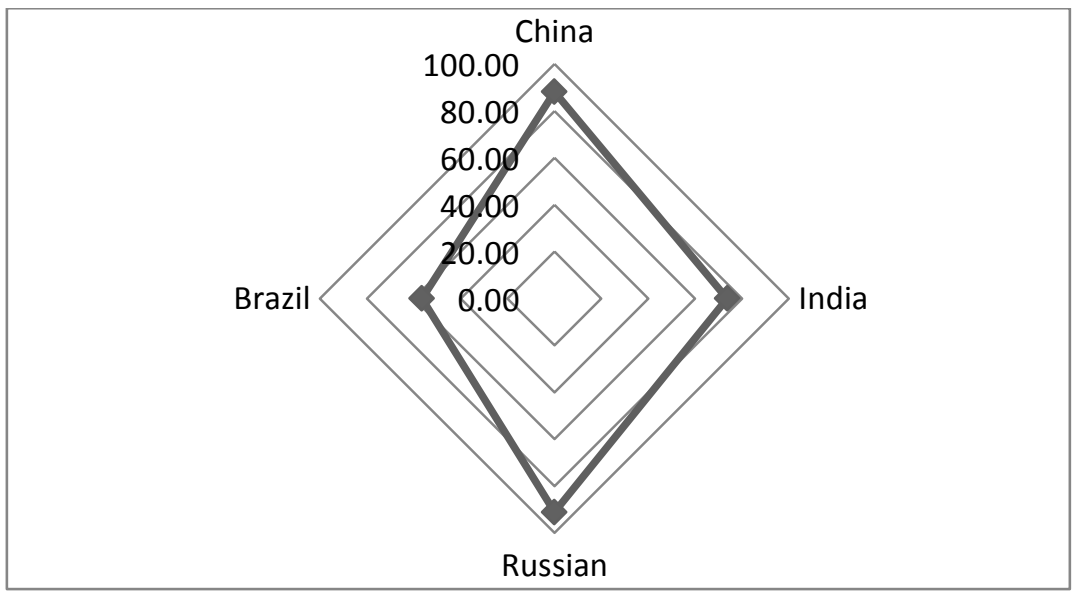

Source: Author's adaptation from WDI databank 
Figure 2(i) represent the eminent rising movement in energy usage (per capita) for BRIC economies between $1991 \& 2012$. India witnesses $68.5 \%$ increment in the energy disposal in 2012 over 1991 (post industrialisation), followed by China and Brazil. Russia seems to lower its consumption from historical energy usage patterns. The overall trend seems to be positive in upcoming years. It is pertinent to note that Russia and China still locates $91 \%$ and $88 \%$ of their total energy requirements from 'fossil fuel based energy sources, comparable to India and Brazil at $74 \%$ and $57 \%$ respectively (Figure 2(ii)). The same broadens detrimental impact on climate.

The rest of the paper is organised as follows. Section 2 provides the literature review followed by objectives of the study. Section 3 examines the synthesis between economic development and carbon emissions using Kuznet Curve (EKC) hypothesis graphically. Section 4 lays down the methodology and section 5 analyses the impact of economic growth on climate through empirical OLS-GMM testing for BRIC and other developing nations. The last section concludes and highlights policy implications.

\subsection{Literature Review}

Researchers have found an inverted U-shaped relationship, monotonically increasing or decreasing, between pollution and a rising per capita income level. Stern (2004) has provided a summary and discussions of the empirical literature (Selden and Song, 1994; Ekins, 1997; the special issue of Ecological Economics, 1998; Stern, 1998; Ansuategi and Perrings, 2000; Cavlovic et al. 2000; Anderson and Cavendish, 2001; Antweiler et al. 2001; Bulte and Soest, 2001; Esty, 2001; Dasgupta et al. 2002; Harbaugh et al. 2002; Khanna, 2002; Lindmark, 2002; Stern, 2002; Millimet et al. 2003). These studies have shown that there is no single relationship between environmental pollution and per capita income that fits all types of pollutants, regions, and time periods. In their review of the Environment Kuznet Curve (EKC) literature, Stern (2004) and Dasgupta (2002) noted the importance of understanding technological progress which is directly linked to the climatic change. Andreoni and Levinson (2001) provided a theoretical explanation of the EKC, assuming economies of scale in pollution control. More recent literature is by Shahbaz (2013), Omri (2013), Arouri (2012), Hossain (2012), Odhiambo (2012), Tsani (2010), Ghosh (2010) and Ozturk (2010) on EKC/ Kuznet Hypotheses.

As per study by Huang, Hwang and Yang (2008), the economic development and GHG emissions in Economies in Transition (EITs) exhibit a hockey-stick curve trend (or called quasi-L-shape curve), that also generates a lot of "hot air" which is significant to the implementation of the Kyoto Protocol. Others such as Vadlamannati (et 
al Tamazian, 2009) advocated that higher degree of economic and financial development decreases the environmental degradation. Their analysis suggests that financial liberalization and openness are essential factors for the $\mathrm{CO}_{2}$ reduction. On the contrary, Managi (2006) argued that there are increasing returns to abating pollution. Empirical evidence on environmental risks in the US agricultural sector since 1970 support the existence of increasing returns. In addition, it estimates the productivity of pollution abatement using refined empirical productivity measurement methods and explicitly control the level of technology. Further, Georgescu-Roegen (1971) and Daly (1977) argue that more economic growth entails more production and consumption activities to satisfy human wants, thus causing more waste, more pollution and more pressure on environmental resources.

Rothman (1998) asserted that consumption is the principal driving force behind environmental impact and that there is much to be learned by taking a consumptionrather than production-based approach, as earlier studies have predominantly done. Because it is trade that allows for a divergence of production and consumption patterns within a region this leads to a discussion of how to consider the role of trade in the context of the EKC hypothesis. The results show the importance of including an environmental productivity variable in the EKC framework. Also, Ozturk (2010) reasons that higher energy consumption accelerates $\mathrm{CO}_{2}$ emissions; although, efficient production technology usage might moderate these emissions over time (Chang, 2010; Omri, 2013). Similarly, Tsani (2010) investigated the causal relationship between energy usage and economic growth for Greece for the period 1960-2006, and purported unidirectional causality that runs from energy usage to economic growth. Additionally, Ghosh (2010) analyses the causal relationship between carbon emissions and economic growth for India using ARDL bounds testing approach supplemented by JohansenJuselius (ML) procedure in a multivariate framework by introducing energy supply, investment and employment for time span 1971-2006. In another study, Arouri (2012) attempted to validate the presence of EKC in 12 MENA Countries over the period 19812005 and, second to depict the turning points until which the development betters the environmental quality in these countries. Their results provide poor evidence in support of the EKC hypothesis the suggesting that all the MENA countries need to decide tradeoff between emissions and growth.

Odhiambo (2012) inspected the causal linkage between CO2 emissions and economic growth in South Africa, using the ARDL-Bounds testing approach. The empirical results show that there is unidirectional causal flow from economic growth to carbon emissions in South Africa. In the case of Romania, Shahbaz (2013) explored the existence of EKC hypothesis over the period of 1980-2010. They endorsed the ARDL 
bounds testing for long run and arrived at the inverted U-shaped relationship between economic growth and CO2 emissions (i.e. the EKC hypothesis is found). Hossain (2012) has established the dynamic causal linkage between carbon dioxide emissions, energy usage, economic growth, foreign trade and urbanization in Japan using time series data for the period of 1960-2009. Short-run unidirectional causalities are detected from energy consumption and trade openness to $\mathrm{CO} 2$ emissions, from trade openness to energy consumption, from carbon dioxide emissions to economic growth, and from economic growth to trade openness. More recently, Omri (2013) has tested the link among CO2 emissions, energy consumption and economic growth using SEM with panel data on 14 MENA countries over the period 1990-2011. The empirical results depict that there is a bidirectional causal relationship between energy consumption and economic growth and a bidirectional causal relationship between economic growth and $\mathrm{CO} 2$ emissions for the region as a whole.

Given all these evidences, therefore, economic development is likely matter for environmental performance. However, there is still limited empirical and graphical evidence on the channels of environmental performance due to output, energy and direct foreign investment expansion on group of developing nations. This paper seeks to fill that gap. The main objective of this paper is to examine whether the economic development along with energy consumption tend to increase the environmental damage or not. To test if the degree of economic development has a systematic relationship with the level of $\mathrm{CO}_{2}$ emissions in a country, we use panel data and adopt the standard approach used in the existing EKC literature. Although, before testing the above empirically, we have identified the relationship between economic growth and environmental impact graphically using EKC hypothesis.

\subsection{Graphical Synthesis using EKC Theory}

The relationship between economic growth and environmental safety has been a subject of constant concern and research from long. The most often adopted methodology for such analyses is the Environmental/ Carbon Kuznets Curve (EKC/ CKC) hypothesis, which hypothesizes that the environmental quality worsens with economic growth, and that their relationship can be expressed in the shape of an inverted-U or bell-shaped curve meaning thereby that at the beginning of economic development, the environmental quality will first wane with economic growth. However, after reaching a peak point (tipping point), the environmental quality may improve with subsequent economic growth (De Bruyn, 2000). It is often mentioned that in the process, developing countries may (based on the past experiences of developed countries) remove 
environmentally harmful subsidies, in order to avoid decay of environmental quality beyond the ecological threshold. Holtz-Eakin and Schwartz (1995) may be the first group to study the EKC relationship with carbon dioxide based on the econometric method. Sun (1999) proposed the peak theory for energy intensity and theorized that at the beginning of industrial development, the energy intensity of a country will rise quickly, then peak and decrease subsequently. Figures 3, 4, 5 and 6 indicate the EKC for BRIC nations from 1966 to 2011. The X and Y axis are commensurate with the EKC postulation.

Figure 3: Environment Kuznets Curve (EKC) for China over the period 1966-2011

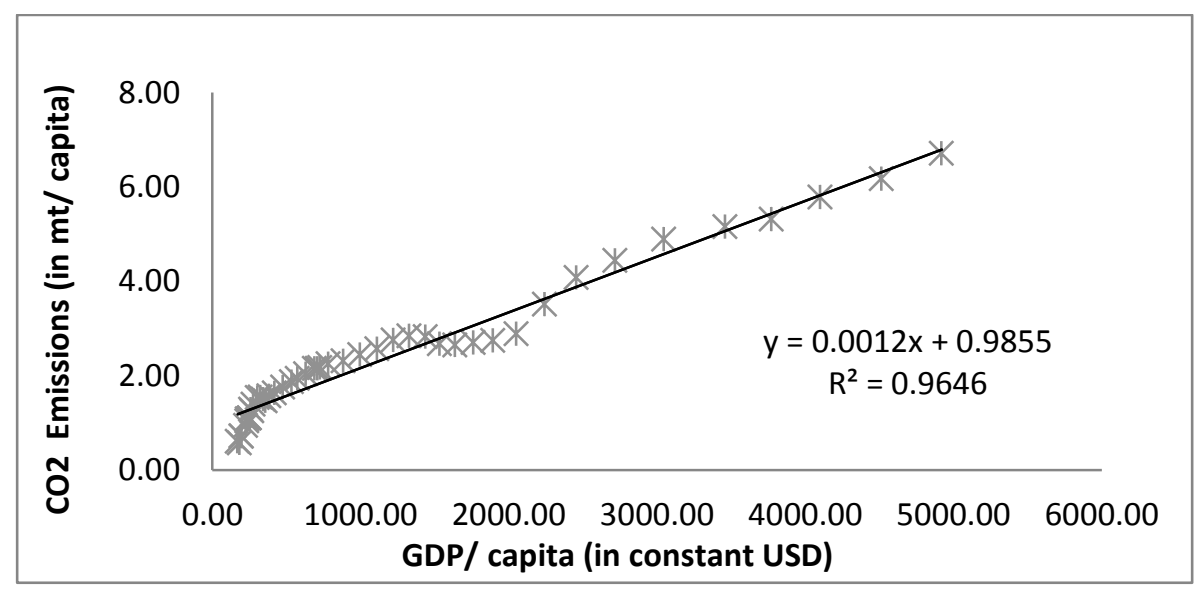

Source: Authors' representation from WDI database on GDP and $\mathrm{CO}_{2}$ emissions

Figure 4: Environment Kuznets Curve (EKC) for India over the period 1966-2011

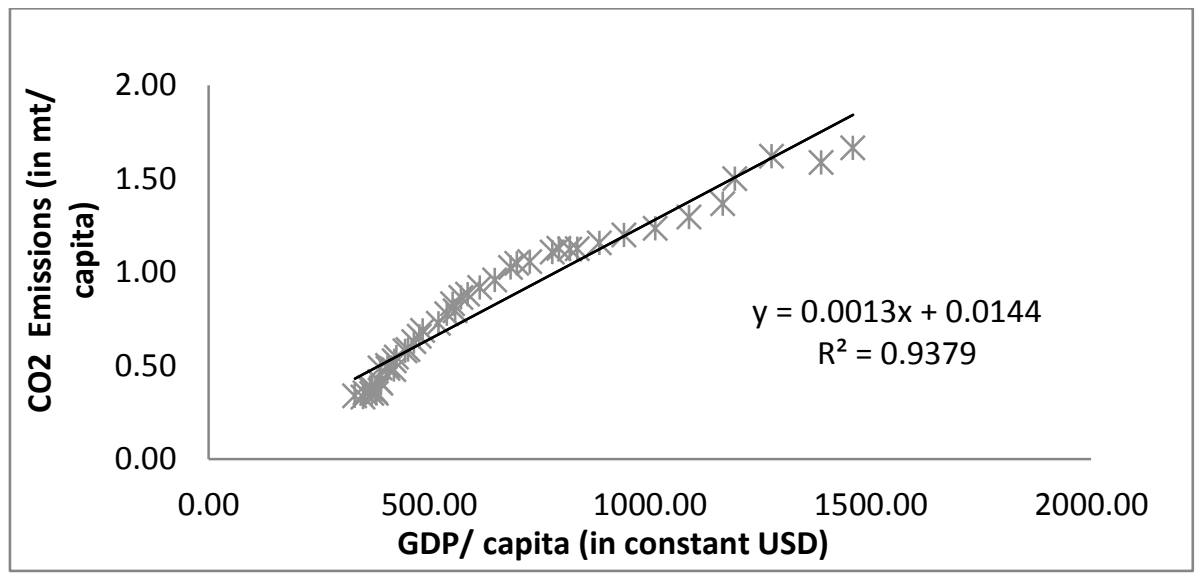

Source: Authors' representation from WDI database on GDP and $\mathrm{CO}_{2}$ emissions 
Figure 5: Environment Kuznets Curve (EKC) for Brazil over the period 1966-2011

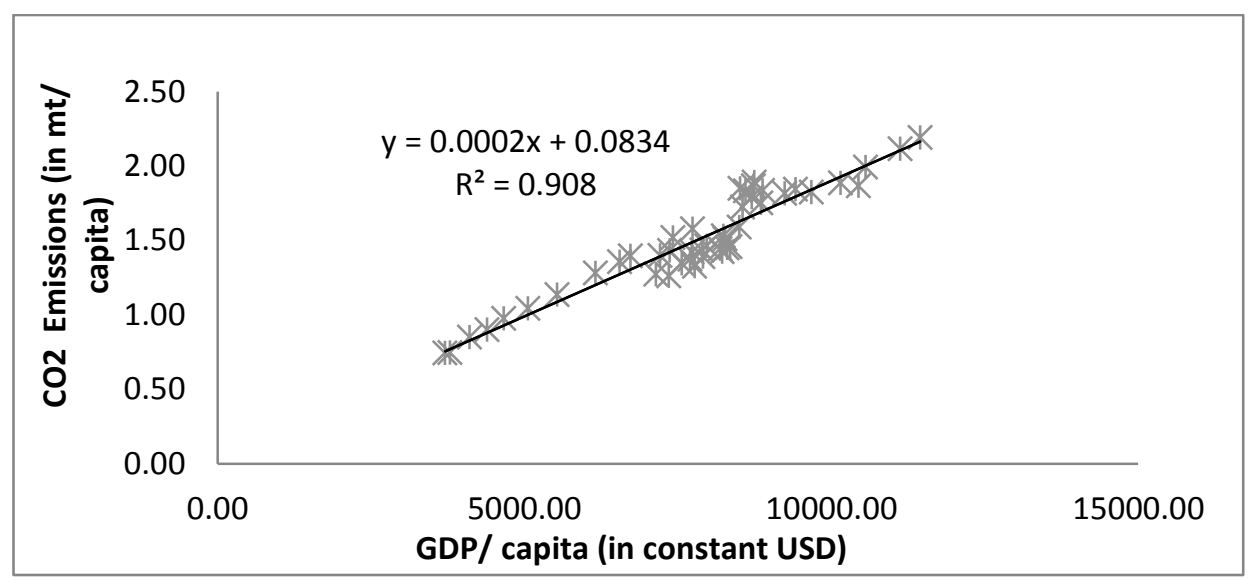

Source: Authors' representation from WDI database on GDP and $\mathrm{CO}_{2}$ emissions

Figure 6: Environment Kuznets Curve (EKC) for Russia over the period 1992-2011

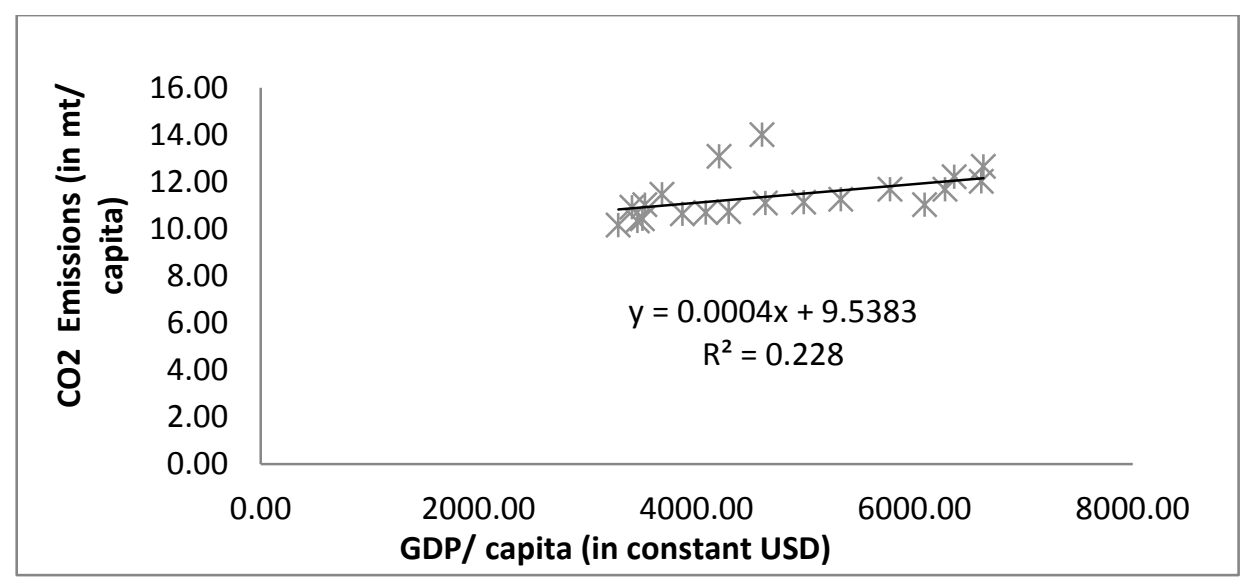

Source: Authors' representation from WDI database on GDP and $\mathrm{CO}_{2}$ emissions Note: Russia's data is available only from 1992.

Figure 3-6 represent the Carbon/ Environment Kuznets curves for BRIC nations from 1966 to 2011. The following are the pertinent observations that surface from the graphical presentation:

(i) All the four nations are still on the surging portion of EKC indicating that the economic growth for this group is complemented by climatic adversity, resulting from growing carbon spacing. The trend doesn't seem to be favourable in near future. 
(ii) Russia and China have higher positive intercept values, followed by India and Brazil. The same indicates the potential that economic development could have on climatic change.

(iii) China and India contain highest positive slope values with corresponding $\mathrm{R}^{2}$ values. The same denotes that these two nations possess the greater intensity and linkage between emissions and GDP per capita, making those carbon-prone economies.

(iv) The trend lines are positively sloping for all four, further emphasizing that 'tipping point' and finally the decreasing trend has a long way to go for this group of nations.

Figure 7 and 8 entail the EKC for developing nations (groups) - including South Asian Region (SAR) and East Asia and Pacific (excluding High Income Countries or HICs).

\section{Figure 7: Environment Kuznets Curve (EKC) for South Asian Region over the period 1992-2011}

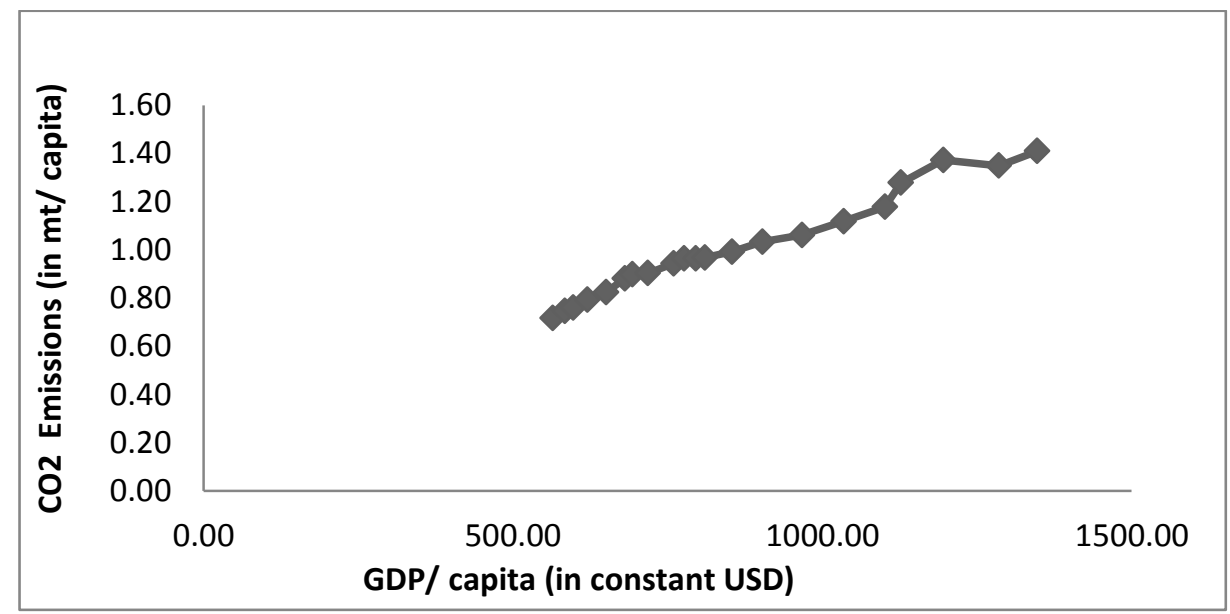

Source: Authors' representation from WDI database on GDP and $\mathrm{CO}_{2}$ emissions

The EKCs for developing nations (Figure 7 and 8) primarily denote that there is an upward positive association between $\mathrm{CO}_{2}$ emissions/ capita (in $\mathrm{mt}$ ) and GDP/ capita (in constant USD). One of the noteworthy point is that East Asia and Pacific nations (excl HICs) have steep EKC in comparison to SAR. The same indicates that East Asian economies face bigger threat among developing nations for unfavorable climatic changes due to economic expansion. The above apparent linkage is tested empirically using GMM methodology in the next section. 
Figure 8: Environment Kuznets Curve (EKC) for East Asia and Pacific over the period 1992-2011

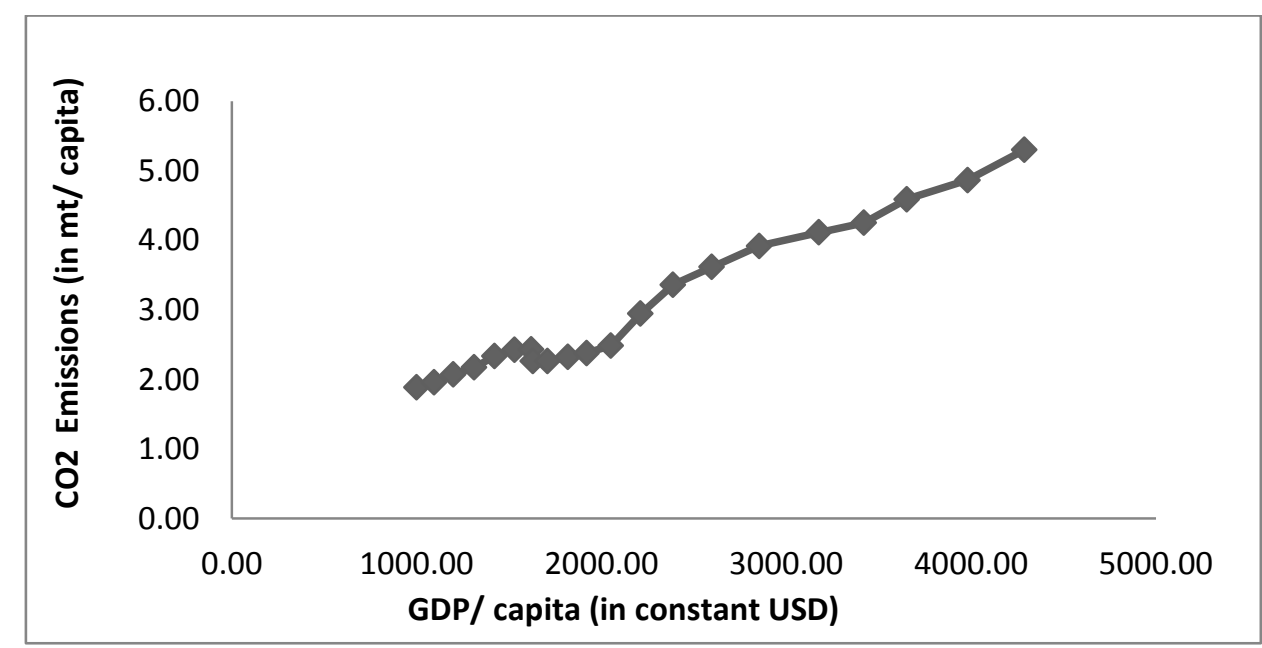

Source: Authors' representation from WDI database on GDP and $\mathrm{CO}_{2}$ emissions

\subsection{Research Methodology}

Since the main objective of this paper is to examine whether economic development along with other growth indicators (such as energy consumption, direct foreign investment) tend to multiply the environmental damage or not, panel data is used as per existing literature from 1991 to 2011 for BRIC and other developing nations (including SAR, UAE, Vietnam, Philippines, Indonesia, Saudi Arabia, Thailand, Argentina and Cambodia). Data statistics are sourced from WDI, World Bank and EFI ${ }^{1}$ Heritage database.

Similar to Tamazian, Chousa and Vadlamannati (2009), the current study has adopted the standard reduced form-modelling approach form. The specification of current empirical model as follows:

$$
\begin{gathered}
\log \left(C_{2 i t}\right)=\alpha+\beta_{1}\left(\operatorname{lgdppc}_{i t}\right)+\beta_{2}\left(F F E C_{i t}\right)+\beta_{3}\left(E U_{i t}\right)+\beta_{4}\left(\log F D I_{i t}\right)+ \\
\beta_{5}\left(F_{i t}\right)+\beta_{6}\left(V A I_{i t}\right)+\beta_{7}\left(S M V A_{i t}\right)+\beta_{8}\left(E I_{i t}\right)+\beta_{9}(C \operatorname{CtryDumm} i t)+\varepsilon_{i t}
\end{gathered}
$$

where $\mathrm{CO}_{2}$ indicates $\mathrm{CO}_{2}$ emission per capita in country $\mathrm{i}$ at time $\mathrm{t}$; gdppc GDP per capital in country $\mathrm{i}$ at time $\mathrm{t}$; FFEC fossil fuel energy consumption (\% of total) in country $i$ at time $t$; EU energy use (kg of oil equivalent per capita) in country I at time $t$; FDI direct foreign investment, net inflows ( $\%$ of GDP) in country $i$ at time $t$; FOI 
financial openness index in country i at time t; VAI Industry, value added (\% of GDP) in country $i$ at time $t$; SMVA stocks traded, total value (current USD) in country $i$ at time $t$; EI energy imports, net (\% of energy use) in country i at time t; Ctry Dumm structural break in database for country $\mathrm{i}$ at time $\mathrm{t}$ and $\varepsilon_{i t}$ is the random error term. These set of variables are corresponding the economic development with financial growth variables inclusion (The detailed explanation and sources of the variables is provided in Annexure $1)$.

Analogically, the current paper tests whether inverted U-shaped envelop effect may be substantiated for BRIC and developing nations or not. The specification to cover this later aim is as follows:

$$
\begin{aligned}
\log \left(C_{2 i t}\right)= & \alpha+\beta_{1}\left(\operatorname{lgdppc}_{i t}\right)+\beta_{2}\left(F F E C_{i t}\right)+\beta_{3}\left(E U_{i t}\right)+\beta_{4}\left(\log _{F D I_{i t}}\right)+ \\
& \beta_{5}\left(F O I_{i t}\right)+\beta_{6}\left(V A I_{i t}\right)+\beta_{7}\left(S M V A_{i t}\right)+\beta_{8}\left(E I_{i t}\right)+\beta_{9}\left(\text { CtryDumm }_{i t}\right)+ \\
& \beta_{10}\left(G D P_{i t}^{2}\right)+\varepsilon_{i t}
\end{aligned}
$$

where the definition of all the variables are the same as that of the first equation. Equation (2) carries GDP growth rate (annual \%) squared values in country $\mathrm{i}$ at time t, $G D P_{i t}^{2}$, to confirm whether $\mathrm{U}$-shaped relationship between $\mathrm{CO}_{2}$ and economic growth exists or not. Control variables presumed while testing the GMM two-step standard error, are gdppc, energy use and FDI.

The rationale behind the selected variables is discussed below.

a) Economic development: Under economic development, Pao and Tsai (2010) find dynamic causal relationships among pollutant emissions, energy consumption and output for a panel of BRIC countries over the period 1971-2005, except for Russia (19902005). In long-run equilibrium energy consumption has a positive and statistically significant impact on emissions, while real output exhibits the inverted U-shape pattern associated with the EKC hypothesis. Chen and Chen et al. (2011) further argues that emissions embodied in different economic activities such as production, consumption, imports, and exports. Additionally, significance of industrial mix and energy supply infrastructure to evaluate impact on carbon emissions is well documented in Auci and Becchetti et al. (2006). Also, Grossman and Krueger (1995), Selden and Song (1994), Holtz-Eakin and Sleden (1995) and Panayotou (1998) debate that the population growth rate is a key needle in determining environmental degradation. The size of population coupled with rise in GDP growth and higher per capita income leads to an increase in demand and, therefore, in an increase in energy consumption. Hamilton and Turton (2002) claim that per capita income and population growth are the vital factors in increasing carbon emissions in OECD countries. 
b) Financial openness: Various studies have underlined the implication of stock markets, financial liberalisation as essential pillars of financial openness/ expansion. Hamilton (1995), Klassen and McLaughlin (1996) and Lanoie et al. (1998) found evidence that capital markets compensate firms with higher environmental performance through a higher valuation of firms' equities. This argument advocates that the more-developed financial capital markets are likely to enjoy a better environmental quality than that of a country with less- developed capital markets (Dasgupta et al., 2002). At the same time, the literature has recognized the importance of FDI impact in the environmental performance (Rock, 1996; Chua, 1999). However, the impact of FDI on environmental degradation is controversial. Eskeland and Harrison (2003) use a panel data set on US outbound direct investment to four countries and find little support for the pollution haven hypothesis ${ }^{2}$. Further, Liang (2006) instituted a negative correlation between FDI and air pollution, proposing that the overall effect of FDI may be beneficial to the environment.

c) Energy control variables: Rising carbon emissions worldwide confirm the need to act and to move away from the current energy trend. By just about any measure - oil supplies, energy security, $\mathrm{CO}_{2}$ or other emissions - such growth in energy demand threatens the sustainability of the sector. In the current infrastructural energy economy of the developing countries, end-use energy services are mainly energized - directly or indirectly - by oil, natural gas, and coal. This fossil fuel based energy sources are responsible for two third of the carbon emissions (one of the major contributor of greenhouse gases pollution). Therefore, the energy imports and energy usage are considered as the control variables in the current study.

\subsection{Empirical Results}

The testing results and estimates for equation on per capita carbon emissions for BRIC and other developing nations are presented in this section. Firstly, the results on $\mathrm{CO}_{2}$ emissions due to economic expansion along with energy control variables are discussed as per equation (model 1). In the later part, the paper throws light on curvilinear relationship between economic growth and $\mathrm{CO}_{2}$ emissions for developing nations as per equation (model 2). The results in Table 1 (model 1) deals with economic development (along with financial openness and energy control variables) and per capita carbon emissions for the panel of BRIC and 13 other developing nations from 1991 to 2011. Additionally, the results of model 2 for curvilinear testing are also attached in Table 1 for the same set of countries. 
The results as per Table 1 show that the economic development variables, GDP per capita, GDP growth rate has significant impact on per capita $\mathrm{CO}_{2}$ emissions. GDP per capita is significant at $1 \%$ indicating further that for every $1 \%$ increase in GDP/ capita, carbon emissions are increasing by $17.5 \%$ in BRIC and other developing nations in the panel dataset of the study. Similarly, the results also indicate that the level of GDP (current USD) has significant impact on the existing carbon emission level in a country.

Table 1: Results of Per Capita Carbon Emissions Equation Function

\begin{tabular}{|l|c|c|}
\hline \multirow{2}{*}{ Variables } & \multicolumn{2}{c|}{ BRIC and 13 developing nations } \\
\cline { 2 - 3 } & Model-1 & Model-2 \\
\hline Constant, L1 & $0.2728966^{* * *}$ & $0.2728966^{* * *}$ \\
\hline Economic Development Variables & & $(0.1750337)^{* * *}$ \\
\hline lgdp per capita & $(0.1750337)^{* * *}$ & $(-0.0003268)^{* *}$ \\
\hline gdp2g & & $(-0.0000126)^{* * *}$ \\
\hline gdp(current USD) & $(-0.0000126)^{* * *}$ & 0.001116 \\
\hline VAI & 0.001116 & $(-0.0574992)^{*}$ \\
\hline Financial Openness Variables & & -0.0024583 \\
\hline FOI & $(-0.0574992)^{*}$ & \\
\hline Logfdi & -0.0024583 & 0.0110192 \\
\hline Control Variables & & 0.0203909 \\
\hline Fossil-fuel energy consumption & 0.0110192 & $\mathrm{p} \mathrm{value} 0.2315$ \\
\hline Ctry Dummy (Structural Breaks) & 0.0203909 & 279 \\
\hline Abond Analysis & No autocorrelation & \\
\hline Sargan Test & Acceptance & 2.0000 \\
\hline Total no. of observations & & \\
\hline
\end{tabular}

Notes: 1. Equations are run on Stata 13.

2. 13 other developing nations include Argentina, Cambodia, Indonesia, Malaysia, Nepal, Pakistan, Philippines, Saudi Arabia, South Africa, Srilanka, Thailand, UAE and Vietnam.

3. Dependent variable: $\log$ (per-capita CO2 emissions)

4. White heteroscedasticity-consistent standard errors are reported in parenthesis.

$5 . *, * *$ and $* * *$ indicate significance at $1 \%, 5 \%$ and $10 \%$ level respectively.

6. Data sources are indicated in annex 1.

The linkage between financial openness and environmental adversity remains contentious. There are several studies that show FDI inflows lead to increase in environmental depletion (Cole and Elliot, 2005; Feridun, 2006). Current results show 
that increase in FDI inflows are associated with lower levels of per capita $\mathrm{CO}_{2}$ emissions. These findings are parallel to List and Co (2000), He (2002), Soysa and Neumayer (2004) and Liang and Guoyong (2006), who indicate that FDI expansion leads to decline in $\mathrm{CO}_{2}$ emissions. Same is the case with Financial Openness Index. For every $1 \%$ increase in financial transparency, the carbon emissions $\left(\mathrm{CO}_{2}\right)$ see a decline @ $5.7 \%$ per capita.

Regarding the energy consumption control variables, the results signify that higher levels of fossil fuel energy consumption (as \% of total requirements) escalate the per capital $\mathrm{CO}_{2}$ emissions. This is due to higher energy-intensive imports of Brazil, China and India. The energy imports of Brazil, China and India surged during post 1990s. The results for curvilinear effect between GDP growth rate and per capita $\mathrm{CO}_{2}$ emissions show that after controlling for other factors, the results confirm the existence of curvilinear relation- ship. The curvilinear results show that as economic growth rate is enhanced its negative influence on per capita $\mathrm{CO}_{2}$ emissions decreases (Model-2 in Table 1). These results support EKC postulation that pollution levels increase as the countries mature, but begin to decrease as rising incomes pass beyond a verge. Current results are similar to obtained in Kraft and Kraft (1978) and Grossman and Krueger (1992), who show an inverted-U shape relationship between pollution levels and income. Thus, as economies develop along with financial openness and development the energyrelated efficiencies are improved, and this in turn reduces energy consumption levels and hence lower $\mathrm{CO}_{2}$ emissions (Model-2, Table 1). This suggests that there is a need to further improve the degree of financial openness and economic development in BRIC and other developing countries to achieve lower environmental mortification in terms of $\mathrm{CO}_{2}$ emissions. Also, country dummy variable to identify the impact of presence structural break on the panel found to be insignificant to impact the $\mathrm{CO}_{2}$ per capita emissions.

The Sargan and Abond test checks further support the robustness of the results. The significance values of both tests validate the acceptance of the hypotheses and hence representing the strength of the outcomes.

\subsection{Conclusion and Policy Implications}

While most empirical studies have focused on the effects of economic growth on environmental performance, the current paper also focused on the pictographic depiction of environment Kuznet curve for BRIC and other developing nations. Additionally, it inspects BRIC and other developing nations to demonstrate whether or not higher degrees of economic advancement lead to higher $\mathrm{CO}_{2}$ per capita emissions. Fossil fuel 
energy consumption are used as the control variables. The paper shows that the economic expansion moves along with $\mathrm{CO}_{2}$ emissions per capita for the developing nations including BRIC economies. At the same time, the curvilinear empirical establishment does find its relevance for the panel considered over here. The EKC graphic denotes that these set of nations currently rest on the upward sloping portion, directing the positive relationship between the two. Further findings indicate that the financial openness is associated with decline in $\mathrm{CO}_{2}$ per capita emissions. In this sense, it is imperative that the respective command can help the markets by corroborating strong policy structure that creates long-term value for greenhouse gas emissions reductions and consistently supports the development of new technologies that lead to a less carbon-intensive economy.

The overall results suggest crucial policy implications. New ancillary policies that are directed to financial openness to attract higher levels of R\&D-related direct foreign investment can decrease the environment depletion. The findings of the present study supports the Copeland and Taylor (2004) postulation who claims that it would be unwise for countries to use trade protection as a means to improve their environment. Moreover, there is a need for a target which aids the local and national government(s) to frame climate change technological policies and regulations (like promotion of low-CO2 emission technologies improvements in traditional and hybridized internal combustion engines, fuel cell vehicles and electric vehicles or imposing fuel efficiency (or economy) standards).

The current study has its limitation of not capturing the effect of innovation and therefore, green economic growth. We further expect that other researchers will use current study's results and methodology to get improved acumens into the economicfinance and environment nexus in other developing countries.

\section{Annexure 1: Data Sources}

\begin{tabular}{|l|l|}
\hline \multicolumn{1}{|c|}{ Variable } & \multicolumn{1}{c|}{ Source } \\
\hline $\mathrm{CO}_{2}$ emissions & World Development Indicators, World Bank \\
\hline Economic Development & World Development Indicators, World Bank \\
\hline Financial Openness & Heritage Foundation \\
\hline Energy Consumption & World Development Indicators, World Bank \\
\hline
\end{tabular}

\section{Endnotes}

1. 'Economic Freedom' is a major determinant of countries' living standards, economic growth, and other indicators of social and economic well-being. 'Economic Freedom' (EF) or 'Economic Liberty' is the ability of members of a society to undertake economic actions. 
2. The pollution haven hypothesis posits that, when large industrialized nations seek to set up factories or offices abroad, they will often look for the cheapest option in terms of resources and labor that offers the land and material access they require. However, this often comes at the cost of environmentally sound practices. Developing nations with cheap resources and labor tend to have less stringent environmental regulations, and conversely, nations with stricter environmental regulations become more expensive for companies as a result of the costs associated with meeting these standards. Thus, companies that choose to physically invest in foreign countries tend to (re)locate to the countries with the lowest environmental standards or weakest enforcement.

\section{References}

Anderson, D., \& Cavendish, W. (2001). Dynamic simulation and environmental policy analysis: beyond comparative statics and the environmental Kuznets curve. Oxford Economic Papers, 53(4), 721-746.

Antweiler, W., Copeland, B. R., \& Taylor, S. M. (2007). Agyeman, Julian, Environmental Justice and Sustainability. In Atkinson/Dietz/Neumayer (eds), Handbook of Sustainable Development, pp. 171-188. Cheltenham, UK/Northampton, MA, USA: Edward Elgar.

Arouri, M. E. H., Youssef, A. B., Mhenni, H., \& Rault, C. (2012). Energy consumption, economic growth and $\mathrm{CO}_{2}$ emissions in Middle East and North African countries. Energy Policy, 45, 342-349.

Auci, S., \& Becchetti, L. (2006). The instability of the adjusted and unadjusted Environmental Kuznets Curves. Ecological Economics, 60(1), 282-298.

Bulte, E. H., \& Van Soest, D. P. (2001). Environmental degradation in developing countries: Households and the (reverse) Environmental Kuznets Curve. Journal of Development Economics, 65(1), 225-235.

Cavlovic, T. A., Baker, K. H., Berrens, R. P., \& Gawande, K. (2000). A meta-analysis of Environmental Kuznets Curve studies. Agricultural and Resource Economics Review, 29(1), 32-42.

Copeland, B., \& Taylor, R. MS, (2004): Trade, Growth, and the Environment. Journal of Economic Literature, 42(1), 7-71. 
80 | FOCUS: Journal of International Business, Volume 4, Issue 1, January-June 2017

Dasgupta, S., Laplante, B., Wang, H., \& Wheeler, D. (2002). Confronting the Environmental Kuznets Curve. The Journal of Economic Perspectives, 16(1), 147-168.

De Bruyn, S. M. (2000). The Environmental Kuznets Curve hypothesis. In Economic Growth and the Environment, pp. 77-98. Netherlands: Springer.

Ekins, P. (1997). The Kuznets curve for the environment and economic growth: examining the evidence. Environment and Planning, 29(5), 805-830.

Eskeland, G. S., \& Harrison, A. E. (2003). Moving to greener pastures? Multinationals and the pollution haven hypothesis. Journal of Development Economics, 70(1), 1-23.

Esty, D. C. (2001). Bridging the trade-environment divide. The Journal of Economic Perspectives, 15(3), 113-130.

Ghosh, S. (2010). Examining carbon emissions economic growth nexus for India: A multivariate cointegration approach. Energy Policy, 38(6), 3008-3014.

Grossman, G. M., \& Krueger, A. B. (1991). Environmental impacts of a North American free trade agreement. National Bureau of Economic Research Working paper no. w3914.

Hamilton, C., \& Turton, H. (2002). Determinants of emissions growth in OECD countries. Energy Policy, 30(1), 63-71.

Harbaugh, W. T., Levinson, A., \& Wilson, D. M. (2002). Reexamining the empirical evidence for an environmental Kuznets curve. The Review of Economics and Statistics, 84(3), 541-551.

Holtz-Eakin, D., \& Schwartz, A. E. (1995). Infrastructure in a structural model of economic growth. Regional Science and Urban Economics, 25(2), 131-151.

Hossain, S. (2012). An econometric analysis for CO2 emissions, energy consumption, economic growth, foreign trade and urbanization of Japan. Low Carbon Economy, 3(3), 92-105. 
Huang, B. N., Hwang, M. J., \& Yang, C. W. (2008). Causal relationship between energy consumption and GDP growth revisited: a dynamic panel data approach. Ecological Economics, 67(1), 41-54.

Klassen, R. D., \& McLaughlin, C. P. (1996). The impact of environmental management on firm performance. Management Science, 42(8), 1199-1214.

Kraft, J., \& Kraft, A. (1978). On the relationship between energy and GNP. The Journal of Energy and Development, 3, 401-403.

Lanoie, P., Laplante, B., \& Roy, M. (1998). Can capital markets create incentives for pollution control? Ecological Economics, 26(1), 31-41.

Lindmark, M. (2002). An EKC-pattern in historical perspective: carbon dioxide emissions, technology, fuel prices and growth in Sweden 1870-1997. Ecological economics, 42(1), 333-347.

Managi, S. (2006). Pollution, natural resource and economic growth: An econometric analysis. International Journal of Global Environmental Issues, 6(1), 73-88.

Millimet, D. L., List, J. A., \& Stengos, T. (2003). The Environmental Kuznets Curve: Real progress or misspecified models?. The Review of Economics and Statistics, 85(4), 1038-1047.

Odhiambo, N.M. (2012). Economic growth and carbon emissions in South Africa: An empirical investigation. Journal of Applied Business Research. 28(1), 37-46.

Omri, A. (2013). $\mathrm{CO}_{2}$ emissions, energy consumption and economic growth nexus in MENA countries: Evidence from simultaneous equations models. Energy Economics, 40, 657-664.

Pao, H. T., \& Tsai, C. M. (2010). $\mathrm{CO}_{2}$ emissions, energy consumption and economic growth in BRIC countries. Energy Policy, 38(12), 7850-7860.

Perrings, C., \& Ansuategi, A. (2000). Sustainability, growth and development. Journal of Economic Studies, 27(1/2), 19-54. 
82 FOCUS: Journal of International Business, Volume 4, Issue 1, January-June 2017

Sachs, G. (2003). Dreaming with BRICs: The Path to 2050 (by Dominic Wilson and Roopa Purushothaman). Global Economics Paper No. 99.

Selden, T. M., \& Song, D. (1994). Environmental quality and development: Is there a Kuznets curve for air pollution emissions?. Journal of Environmental Economics and Management, 27(2), 147-162.

Shahbaz, M., Mutascu, M., \& Azim, P. (2013). Environmental Kuznets Curve in Romania and the role of energy consumption. Renewable and Sustainable Energy Reviews, 18, 165-173.

Stern, D. I. (2004). The rise and fall of the Environmental Kuznets Curve. World Development, 32(8), 1419-1439.

Tamazian, A., Chousa, J. P., \& Vadlamannati, K. C. (2009). Does higher economic and financial development lead to environmental degradation: Evidence from BRIC countries? Energy policy, 37(1), 246-253.

Tsani, S. Z. (2010). Energy consumption and economic growth: A causality analysis for Greece. Energy Economics, 32(3), 582-590. 